\title{
sciendo
}

DOI 10.2478/sbe-2019-0027

SBE no. 14(2) 2019

\section{SOME INSIGHTS ON THE WORLD'S MOST INNOVATIVE COMPANIES AND THEIR DEFINING CHARACTERISTICS}

\author{
OGREAN CLAUDIA \\ Lucian Blaga University of Sibiu, Romania
}

\begin{abstract}
:
As time went by, innovations have not only accompanied, but also shaped the evolution of humankind, while being its loyal source of progress; and they have played the same leading role at organizational (firm/company) level - although, if moving beyond the cumulative (global) outputs, a thorough (unit based) analysis would reveal that (the same) innovations have always distinguished between first movers and followers, innovators and imitators, winners and losers. Thus, the most innovative companies have had the opportunity of capitalizing on their realized innovation potential as industry innovation leaders, while the other companies have had to search for other types of strategic positioning in order to be competitive. But realities and trends are quite different nowadays - the unprecedented (time-related) pace and (space-related) diffusion rate that characterize innovations ask for companies to fundamentally change their approach on innovation: under the new circumstances, innovation can no longer be an option (but a perennial must - a marathon, not a sprint) and each company has to become (to a certain degree) an innovative company - in order to survive. Against this background, the paper aims to: (a). provide an outline of the main categories/topics the literature on organizational innovation deal with; (b). identify the profile and main characteristics of innovative companies; (c). compare and contrast two globally recognized rankings of the most innovative companies (BCG \& PwC) in terms of companies' characteristics.
\end{abstract}

Key words: Innovation; Innovative organization/company; World's Most Innovative Companies

\section{Introduction}

Either it is defined as "creation of a viable new offering" (Keeley et al., 2013), or "successful introduction of a new product, process, or business model" (Rothaermel, 2017), it is widely accepted that "innovation is more than simply coming up with good ideas: it is the process of growing them into practical use" (Tidd \& Bessant, 2018), able to provide a company with strategic advantage (Tidd \& Bessant, 2018). But things are more complicated than that, as "innovation is both an outcome and a process, a fact and an act. An innovative outcome involves the successful application of new ideas, which results from organizational processes that combine various resources to that end" (Dodgson et al., 2013). 
Moreover, if adding to this (already complex) equation the time dimension - that absorbs and (at different degrees) amplifies the effects, leading to unexpected new circumstances asking for (other) innovative solutions, it becomes clear why innovation has drawn the attention of numerous scholars - trying to decipher and valorize its multiple facets and valences, while constantly adding new ones - and thus contributing to the enrichment of both its theoretical and practical fields. To support this statement, a quick search on Clarivate Analytics' Web of Science (WoS) Core Collection (http://apps.webofknowledge.com) reveals a total of 242 results in 1975 for the "Innovation" Topic - out of which 33 associated to Management Category and a total of 24.890 results in 2018 for the same topic - out of which 3.813 associated to Management Category; if cumulating the results for the Innovation topic during the 1975 to 2018 time span, a total of 244.561 results is provided, out of which 45.169 associated to Management Category.

A content analysis of the results provided by the Google Academic platform (https://scholar.google.ro) shows about 1.200 .000 results for "Innovation" by the end of 2018, the most relevant (in terms of number of citations) referring to topics such as: National innovation systems (Nelson, 1993); National systems of innovation (Lundvall, 2010); The sources of innovation (Von Hippel, 2007); The management of innovation (Bruns \& Stalker, 1961); Innovation and entrepreneurship (Drucker, 2014); Economics of industrial innovation (Freeman, 2013); Architectural innovation (Henderson \& Clark, 1990); Innovation and growth in the global economy (Grossman \& Helpman, 1991); Absorptive capacity: A new perspective on learning and innovation (Cohen \& Levinthal, 1990); Innovation and learning: the two faces of $R \& D$ (Cohen \& Levinthal, 1989).

A more specific search for the (strategic) management related results on Innovation leads to the following categories of findings:

- On innovation as organizational process and/or outcome - Robertson (1967) analyzes The process of innovation and the diffusion of innovation; Salaman and Storey (2002) discuss Managers' theories about the process of innovation; Kaufmann and Tödtling (2001) study Science-industry interaction in the process of innovation: the importance of boundary-crossing between systems.

- On the relationship between organizational innovation and firm performance Gunday et al. (2011) evaluate the Effects of innovation types on firm performance; Camisón and Villar-López (2014) investigate Organizational innovation as an enabler of technological innovation capabilities and firm performance; Kleinknecht and Mohnen (2001) make an Econometric explorations of survey data on Innovation and firm performance;

- On the determinants and sources of innovation - Von Hippel (2007) explores The sources of innovation; Mohr (1969) analyzes the Determinants of innovation in organizations; Damanpour (1991) develops A meta-analysis of effects of determinants and moderators as regards Organizational innovation:

- On innovation types / forms and application areas - Abernathy and Utterback (1978) evaluate the Patterns of industrial innovation; Damanpour et al. (1989) study The relationship between types of innovation and organizational performance;

- On strategic innovation and innovation strategy - Markides (1998) analyzes Strategic innovation in established companies; Schlegelmilch et al., (2003) explore 
Strategic innovation: the construct, its drivers and its strategic outcomes; Amidon, (2009) investigates Innovation strategy for the knowledge economy; Anthony et al. (2006) argue on Mapping your innovation strategy;

- On the risks of innovation - Nechaev et al. (2014) estimate The risks of innovation activities in enterprises; Glor (2002) explores Innovation traps: Risks and challenges in thinking about innovation; Fernandes and Paunov (2012) evaluate The risks of innovation: Are innovating firms less likely to die?;

- On the innovation - internal \& external - ecosystem - Jackson (2011) study What is an innovation ecosystem; de Vasconcelos Gomes et al. (2018) are Unpacking the innovation ecosystem construct: Evolution, gaps and trends; Smith (2006) argues on Building an innovation ecosystem: Process, culture and competencies;

- On organizing for innovation - (a). open innovation: Chesbrough (2003) discusses Open innovation as The new imperative for creating and profiting from technology; Gassmann et al. (2010) analyze The future of open innovation; (b). ambidexterity: Lin et al. (2013) talk about Managing the exploitation/exploration paradox: The role of a learning capability and innovation ambidexterity; Andriopoulos and Lewis (2009) evaluate Exploitation-exploration tensions and organizational ambidexterity in Managing paradoxes of innovation;

- On new forms of innovation - (a). Social innovation: Mulgan et al. (2007) assess Social innovation: what it is, why it matters and how it can be accelerated; Murrayet al. (2010) propose The open book of social innovation; (b). Eco-innovation: Andersen (2008) advances Eco-innovation-towards a taxonomy and a theory; Bossle et al. (2016) study The drivers for adoption of eco-innovation; (c). Sustainable innovation: Schot and Geels (2008) evaluate Strategic niche management and sustainable innovation journeys: theory, findings, research agenda, and policy; McElroy (2003) proposes The new knowledge management: Complexity, learning, and sustainable innovation.

\section{The innovative organization / company}

The amount and diversity of the studies and researches on (organizational) innovation proves the complexity that characterizes both the theory and practice of innovation at firm/company level, as well as their multiple facets, valences and outcomes. But they are only (disparate) dots that need to be connected into a coherent (while dynamic and idiosyncratic) pattern in order for companies to successfully target a long term strategic advantage - that is, to become innovative organizations.

And this would be quite a challenging endeavor - as "building innovative organizations entails not only matching structural forms with technological and market opportunities, but also embedding the capacity for learning and knowledge creation within team processes and social relationships" (Lam, 2011). An integrated holistic approach is needed - because "no single innovation tool or method will deliver consistent, profitable breakthroughs, and neither will a hodgepodge of misaligned or poorly integrated practices. (...) Skills, tools, metrics, processes, platforms, incentives, roles, and values all have to come together in one supercharged, all-wheel-drive, race-winning innovation machine" 
(Hamel \& Tennant, 2015) - whose validation will eventually be the innovative organization - "one that constantly questions and reviews itself, trying to achieve a relationship of fit with its environment, turning the environment into a projection of its own identity" (VerduJover et al., 2005).

Basically, the literature in the field of innovative organization (company/firm) is developed around two main approaches: (a). one that emphasizes on particular aspects/dimensions of the innovative organizations (Becker and Whisler, 1967; Beer and Walton, 1987; Wakelin 1998; Seidler-de Alwis and Hartmann, 2008; Lockwood and Walton, 2010), and (b). another that embraces rather a holistic view on the subject (Christiansen, 2000; Denervaud and Chatin, 2011; Keeley et al., 2013; Chauvel and Borzillo, 2017; Tidd and Bessant, 2018). For the purposes of this paper, the attention will be turn towards the later line of thoughts; thus:

Embracing a "management systems that encourage innovation" perspective, Christiansen's (2000) work (on Building the innovative organization) argues for the need of a new paradigm of innovation at company level. Aware that "the great wave of innovations that has swept out from electronics, software, telecommunications, chemistry, and biology has touched every industry on the planet", Christiansen (2000) proposes a radical shift in the way companies (through their managers) approach innovation, as follows: "The rule used to be, 'Don't innovate unless you have to'. The rule now is, 'Innovate or die!'. Companies (...) must develop ways of managing themselves that encourage innovation, or they will see their competitors beat them at every turn" (Christiansen, 2000). As Christiansen's (2000) work was built upon "a comparative study of innovation management practices in twenty companies", it is likely for it to be able "to help managers learn how to encourage innovation".

From "an 'organic' analogy between genetics and a company's ability to innovate" perspective, Denervaud and Chatin's (2011) endeavor (on DNA Profiling: The Innovative Company) firstly introduces the concept of the "DNA of an innovative company" - "its capacity to mix its elementary nitrogenous bases (...the key challenges a company face...) and offer a successful way to innovate in a particular market" - and then explains how "innovative companies evolve through permanent confrontation between their DNA and the ever-changing environment in which they live" (Denervaud and Chatin's, 2011). Considering the ability to innovate "more than ever a prerequisite of evolution and survival for a company", Denervaud and Chatin (2011) conclude that "a business has to find the keys to mechanisms that help it cope with the law of natural selection. Its DNA may well mutate through its own replication mechanisms or under the influence of outside phenomena".

Embracing a knowledge-based perspective, Chauvel and Borzillo's (2017) work (on The Innovative Company: An III-defined Object) addresses the nowadays "challenge of competitiveness and innovation" by "outlining and defining an innovative company in the age of knowledge". The study identifies "three levers that make up the profile of the innovative company": (a). an entrepreneurial posture (encompassing vision, commitment, flexible structure, and decentralization); (b). a culture centered on innovation (based on accountability, autonomy, risk taking, and commitment); and (c). management focused on innovation (that brings together managerial innovation, leadership, and learning) (Chauvel 
and Borzillo, 2017). In line with their cognitive, knowledge based approach, Chauvel and Borzillo (2017) outline that "first of all, the innovative company is, of course, one that cultivates innovation as a principle of life and a core value", and, from a broader perspective, "a mindset that is applied in strategy, management and practice".

Addressing the question "how you can innovate effectively" and aiming "to make innovation a systematic approach" (because, according to them, "innovation almost never fails due to a lack of creativity. It's almost always because of a lack of discipline"), Keeley et al. (2013) propose the Ten Types of Innovation framework. The framework is based on the (empirically validated) premise that "all great innovations, throughout history, comprise some combination of ten basic types organized within three categories". The three building blocks and their specific types of innovation refer to: configuration (grouping: profit model, network, structure, and process innovation), offering (materialized into product performance and product system innovation), and experience (gathering: service, channel, brand, and customer engagement innovation) (Keeley et al., 2013); to complement their version of the Periodic Table, the authors added over 100 tactics "which can be usefully combined to form winning innovation plays" (Keeley et al., 2013).

From an integrated, innovation management perspective, Tidd and Bessant (2018) build their endeavor (on Managing innovation: integrating technological, market and organizational change) on the argument that "those organizations that are consistently successful at managing innovation outperform their peers in terms of growth and financial performance" - which leaves no much room for other solutions than "building the innovative organization" one. The authors argue that an innovative organization is about "an integrated set of components that work together to create and reinforce the kind of environment which enables innovation to flourish" (Tidd \& Bessant, 2018). And these components refer to the following: shared vision, leadership and the will to innovate; appropriate structure; key individuals; effective team working; high-involvement in innovation; creative climate; and external focus (Tidd \& Bessant, 2018); in case of (most likely) discontinuous conditions, this model would have to be complemented with another three components: continuing and stretching individual development; extensive communication; and learning organization (Tidd \& Bessant, 2018).

\section{BCG's Most Innovative Companies Report}

Since 2005 (and except for 2011) Boston Consulting Group (BCG) annually releases The Most Innovative Companies Report and Ranking - based on a global survey of senior executives representing a variety of industries. The ranking methodology for the 50 most innovative companies has been revised / refined for a few times since 2005 (https://www.bcg.com/publications/interactives/2019-most-innovative-companies.aspx) so that, if prior to 2008 the ranking was exclusively based on respondents' choices, today "the ranking is based on three factors: global innovation executives' votes for the most innovative companies outside their industry, their votes for the most innovative companies inside their industry, and company financial performance" (BCG, 2019).

Despite the methodological differences through the years, there are eight companies - named by BCG "steady innovators" - that have appeared on top 50 most 
innovative companies list every single year since 2005 (Fig.1). This performance is a recognition of these companies' both continuous search for innovation and consistent results towards it - embodied into "breakthrough products, innovative processes, new and differentiated business models, or unique customer experiences" (BCG, 2018).

Fig. 1. BCG's Steady Innovators 2005-2018

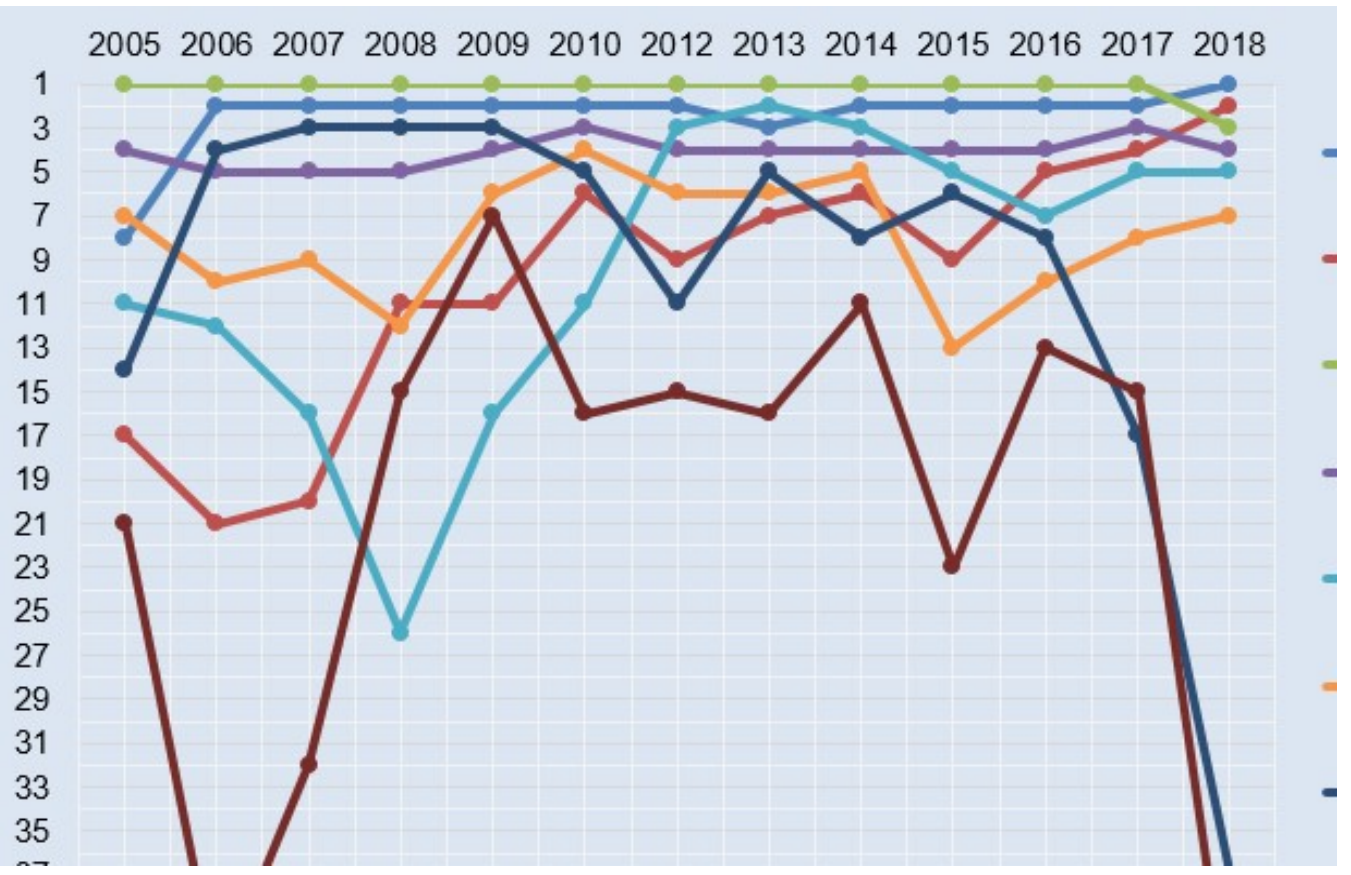

Source of data: BCG, 2019

A closer look at these companies reveals the following:

- six of them belong to the Tech \& telecom industry (Alphabet/Google, Apple, Microsoft, Samsung, IBM, and HP Inc.), while the Consumer \& retail industry and the Automotive industry are represented by one company each (Amazon and Toyota respectively);

- there are three companies (Alphabet/Google, Apple, and Microsoft) - all of them belonging to the Tech \& telecom industry - that have never left the top 10 most innovative companies since 2005;

- HP Inc. has experienced the largest rank span (between the $7^{\text {th }}$ place it occupied in 2009 and the $44^{\text {th }}$ place in 2018), closely followed by Toyota (the $3^{\text {rd }}$ innovator in 2009 and the $37^{\text {th }}$ in 2018);

- $\quad$ at the other end of the spectrum, Microsoft's rank as global innovator has only varied between the $5^{\text {th }}$ place (between 2006-2008) and the $3^{\text {rd }}$ place (in 2010 and 2017); a similar narrow rank span characterizes Apple - but with quite a different dynamic: after 12 years of absolute supremacy, in 2018 Apple has left the first position and dropped on the third place as global innovator, while Alphabet/Google (lowest rank: 8 - in 2005) has taken the lead, followed on the second place by Amazon (lowest rank: 21 - in 2006). 
As regards the Top 10 most innovative companies according to BCG (Fig. 2 and Table 1), the 2019 list (revealing the 2018 ranking of the most innovative companies):

- registers the loss of Apple's leadership and the rise of Alphabet/Google as the most innovative company;

- $\quad$ gathers companies belonging to (only) four industries: Tech \& telecom (represented by 6 companies - Alphabet/Google, Apple, Microsoft, Samsung, IBM, and Facebook), Consumer \& retail (represented by two companies - Amazon and Adidas), Media \& entertainment (one company - Netflix) and Automotive (one company - Tesla);

- provides quite interesting insights on the percentage change for some of the relevant (financial) indicators that characterize top 10 companies: revenue, EBIT, and TSR on the one hand, and R\&D spending, on the other hand; thus, comparing to the previous year:

- a $24,1 \%$ average increase in Revenue has been accompanied by a $23,6 \%$ increase of R\&D spending;

- Tesla's revenue has experienced the biggest increase (68\%) - comparing to IBM, which was the only top 10 company with a negative trajectory as concerns its revenue $(-1 \%)$ - and the biggest increase in R\&D spending $(65,2 \%)$ - comparing to the same IBM, which has registered only a $0,6 \%$ increase of its R\&D spending;

- Apple's increase in terms of R\&D spending $(15,3 \%)$ is more than double comparing to the increase it has registered in terms of Revenue $(6,3 \%)$; on the other hand, despite their decrease of Revenue (with 1\%), IBM has slightly increased their R\&D Spending (with 0,6\%);

- Apple's TSR has increased the most (with 94,7\%), while Microsoft was the only company who's TSR has decreased (with 1,5\%);

- Netflix has registered the biggest EBIT increase $(120,8 \%)$, while IBM's EBIT has decreased (with 16\%).

Fig. 2. BCG's Top 10 Most Innovative Companies 2018

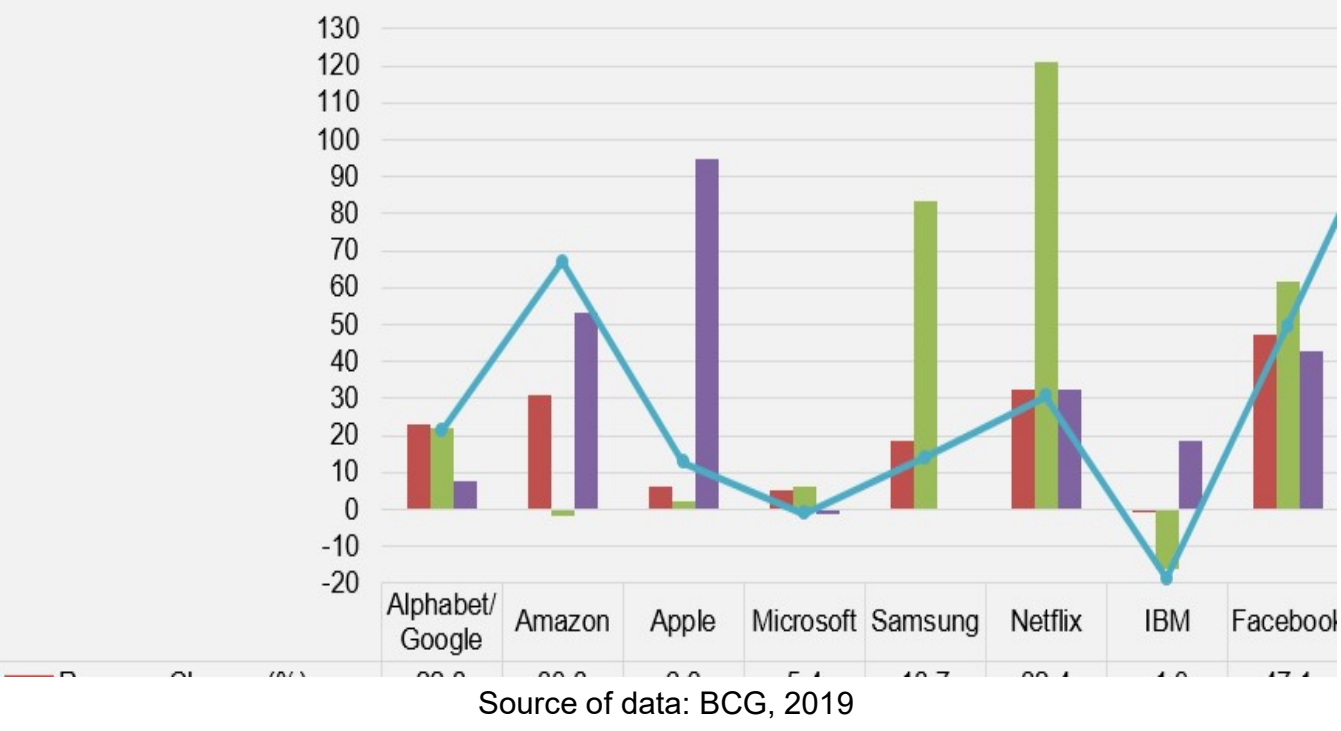


Table 1. BCG's Top 10 Most Innovative Companies 2016-2018

\begin{tabular}{|l|l|l|l|l|l|l|}
\hline \multirow{2}{*}{ Rank } & $\mathbf{2 0 1 6}$ & $\mathbf{2 0 1 7}$ & $\mathbf{2 0 1 8}$ \\
\cline { 2 - 6 } & Company & Industry & Company & Industry & Company & Industry \\
\hline $\mathbf{1}$ & Apple & Tech \& telecom & Apple & Tech \& telecom & $\begin{array}{l}\text { Alphabet } \\
\text { IGoogle }\end{array}$ & Tech \& telecom \\
\hline $\mathbf{2}$ & Google & Tech \& telecom & Google & Tech \& telecom & Amazon & $\begin{array}{l}\text { Consumer } \\
\text { \& retail }\end{array}$ \\
\hline $\mathbf{3}$ & Tesla & Automotive & Microsoft & Tech \& telecom & Apple & Tech \& telecom \\
\hline $\mathbf{4}$ & Microsoft & Tech \& telecom & Amazon & $\begin{array}{l}\text { Consumer } \\
\text { \& retail }\end{array}$ & Microsoft & Tech \& telecom \\
\hline $\mathbf{5}$ & Amazon & $\begin{array}{l}\text { Consumer \& } \\
\text { retail }\end{array}$ & $\begin{array}{l}\text { Samsung } \\
\text { (Group) }\end{array}$ & $\begin{array}{l}\text { Tech \& telecom } \\
\text { Samsung } \\
\text { (Electronics) }\end{array}$ & Tech \& telecom \\
\hline $\mathbf{6}$ & Netflix & $\begin{array}{l}\text { Media \& } \\
\text { entertainment }\end{array}$ & Tesla & Automotive & Netflix & $\begin{array}{l}\text { Media \& } \\
\text { entertainment }\end{array}$ \\
\hline $\mathbf{7}$ & $\begin{array}{l}\text { Samsung } \\
\text { (Group) }\end{array}$ & Tech \& telecom & Facebook & Tech \& telecom & IBM & Tech \& telecom \\
\hline $\mathbf{8}$ & Toyota & Automotive & IBM & Tech \& telecom & Facebook & Tech \& telecom \\
\hline $\mathbf{9}$ & Facebook & Tech \& telecom & Uber & $\begin{array}{l}\text { Transportation } \\
\text { \& travel }\end{array}$ & Tesla & Automotive \\
\hline $\mathbf{1 0}$ & IBM & Tech \& telecom & Alibaba & $\begin{array}{l}\text { Consumer } \\
\text { \& retail }\end{array}$ & Adidas & $\begin{array}{l}\text { Consumer } \\
\text { \& retail }\end{array}$ \\
\hline
\end{tabular}

Source of data: BCG

If looking at BCG's last three series (2016-2018) of Top 10 Most Innovative Companies (Table 1):

- there are eight companies that are present in all the three of them (Alphabet/Google, Amazon, Apple, Microsoft, Samsung, IBM, Facebook, and Tesla): six companies are amongst the (eight) companies identified by BCG as Steady Innovators since 2005, while the other two of them have only been founded in 2003 - Tesla (which has joined BCG's list of 50 Most Innovative Companies in 2013 - from the $41^{\text {st }}$ position) - and 2004 respectively - Facebook (which has joined BCG's list of 50 Most Innovative Companies in 2008 - from the $25^{\text {th }}$ position);

- the other (two) companies that complete BCG's Top 10 Most Innovative Companies are: Netflix and Toyota - in 2016, Uber and Alibaba - in 2017, and Netflix and Adidas in 2018: except from Toyota, which is one of the Steady Innovators on BCG's Most Innovative Companies lists, the other four companies are rather new comers: Netflix has joined BCG's list of 50 Most Innovative Companies in 2015, Uber - in 2016 (while leaving it in 2018), and Adidas and Alibaba - in 2017.

Overall, with reference to its rankings during the 2016-2018 time span, BCG argues for the power of digitalization - and its cohort of business applications - to transform both the search for innovation and the (resulted) global architecture of innovation, while redefining / reshaping industries: (a). the "2016 list of the 50 most innovative companies highlights the impact of the digital revolution. (...) BCG's $11^{\text {th }}$ annual global survey on the state of innovation shows that using technology to secure an innovation advantage is no longer the purview of tech companies." (Ringel et al., 2017); (b). as regards the 2017 list, "at leading innovators, R\&D and new-product development have become digital endeavors. (...) The trend is pervasive across industries, penetrating what were heretofore the most stolid and conservative businesses" (Ringel et al., 2018); 
(c). moreover, in 2018, "all of the ten highest-ranking companies - and many in the top 50 - use Al, platforms, and ecosystems to enable themselves and others to pursue new products, services, and ways of working" (Ringel et al., 2019).

\section{PwC's Global Innovation 1000 Study}

PwC's Global Innovation 1000 Study embraces quite a different perspective on innovation, as it actually "tracks the companies that spend the most on innovation" (Jaruzelski, \& Dehoff, 2010). Started by Booz \& Company in 2005, this "annual analysis of the 1000 publicly held companies that spend the most on research and development" (Jaruzelski, Chwalik, \& Goehle, 2018) is developed based on a series of key financial performance indicators ("including sales, gross profit, operating profit, net profit, historical R\&D expenditures, and market capitalization"), complemented by an online survey of "innovation leaders and managers around the world" (https://www.strategyand.pwc.com/innovation1000\#Methodology|GlobalKeyFindingsTabs4 ). Since 2009, as part of the study's survey, respondents are (also) asked to nominate what they consider to be the most innovative companies in the world - therefore allowing PwC to compare and contrast the Top innovators versus the Top spenders.

Thus, PwC's 2018 Global Innovation 1000 Study reveals (Fig. 3):

- a 45,35\% increase in R\&D Spending made by the Top 1000 companies between 2009 and 2018 (with a 9-year CAGR of 4,24\%); interestingly, the series' first interval registers the only decrease in R\&D spending (with 5,6\% in 2010 comparing to 2009), while its last interval registers the highest increase (with 11,4\% in 2018 comparing to 2017);

- quite different dynamics as regards the R\&D Intensity (R\&D expenditure as a percentage of Revenue) of the Top 1000 companies: a 25\% increase in R\&D Intensity between 2009 and 2018 corresponds to three intervals defined by the decrease of R\&D Intensity (with percentages varying from 2\% in 2012 comparing to 2011 and 5,5\% in 2011 comparing to 2010 and) and six intervals defined by the increase of R\&D Intensity (with percentages varying from $0,02 \%$ in 2018 comparing to 2017 and $13,4 \%$ in 2016 comparing to 2015). 
Fig. 3. PwC's Global Innovators 1000: R\&D Spending versus R\&D Intensity

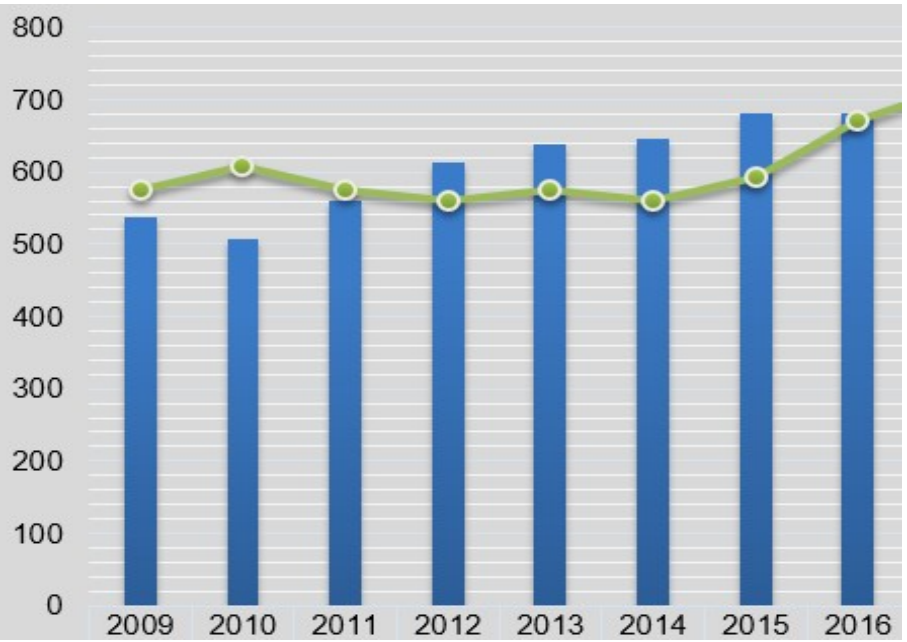

Source of data: PwC, 2018

Against this background, if considering PwC's Top 10 R\&D Spenders versus PwC's Top 10 Innovators in 2018 (Table 2 and Fig. 4) - lists that (only) share six companies - Apple, Amazon, Alphabet, Microsoft, Samsung, and Intel - while being differentiated by four: Volkswagen, Roche, Johnson \& Johnson, and Merck (companies which complete the Top 10 Spenders), and Tesla, Facebook, General Electric, and Netflix (companies which complete the Top 10 Innovators):

Table 2. PwC's Top 10 Spenders vs PwC's Top 10 Innovators 2016-2018

\begin{tabular}{|l|l|l|l|l|l|l|}
\hline \multirow{2}{*}{} & \multicolumn{2}{|c|}{ 2016 Top 10 } & \multicolumn{2}{c|}{ 2017 Top 10 } & \multicolumn{2}{c|}{ 2018 Top 10 } \\
\cline { 2 - 7 } & Spenders & Innovators & Spenders & Innovators & Spenders & Innovators \\
\hline $\mathbf{1 .}$ & Volkswagen & Apple & Amazon & Alphabet & Amazon & Apple \\
\hline $\mathbf{2 .}$ & Samsung & Alphabet & Alphabet & Apple & Alphabet & Amazon \\
\hline $\mathbf{3 .}$ & Amazon & $3 \mathrm{M}$ & Intel & Amazon & Volkswagen & Alphabet \\
\hline $\mathbf{4 .}$ & Alphabet & Tesla & Samsung & Tesla & Samsung & Microsoft \\
\hline $\mathbf{5 .}$ & Intel & Amazon & Volkswagen & Microsoft & Intel & Tesla \\
\hline $\mathbf{6 .}$ & Microsoft & Samsung & Microsoft & Samsung & Microsoft & Samsung \\
\hline $\mathbf{7 .}$ & Roche & Facebook & Roche & GE & Apple & Facebook \\
\hline $\mathbf{8 .}$ & Novartis & Microsoft & Merck & IBM & Roche & GE \\
\hline $\mathbf{9 .}$ & Johnson \& & GE & Apple & Facebook & $\begin{array}{l}\text { Johnson \& } \\
\text { Johnson }\end{array}$ & Intel \\
\hline $\mathbf{1 0 .}$ & Toyota & IBM & Novartis & Alibaba & Merck & Netflix \\
\hline
\end{tabular}

Source of Data: PwC, 2016-2018

Top 10 spenders -2018

- have spent between $\$ 10,2 B$ (Merck) and \$22,6B (Amazon) on R\&D, with a R\&D intensity varying between $5,1 \%$ (Apple)
Top 10 Innovators - 2018

- have spent between \$1,1B (Netflix) and \$22,6B (Amazon) on R\&D, with a R\&D intensity varying between $4 \%$ (GE) and 
and $25,4 \%$ (Merck);

- have spent together $\$ 138,5 B$ on R\&D which represents: (a). $17,7 \%$ of the total R\&D spending made by the Global Innovation 1000 companies (\$782B); (b). a $14,8 \%$ increase compared to 2017 , when the R\&D spending of the Top 10 R\&D Spenders $(\$ 120,6 B)$ has represented $17,2 \%$ of the total $R \& D$ expenditure made by the Global Innovation 1000 companies (\$702B);

- gathers companies belonging to the following (6) industries: Automobiles and components

(Volkswagen), Pharmaceuticals, biotechnology and life sciences (Roche, Johnson \& Johnson, and Merck), Retailing (Amazon), Semiconductors and semiconductor equipment (Intel), Software and services (Alphabet and Microsoft), and Technology hardware and equipment (Apple and Samsung).

A quick look back, at PwC's Top 10 Spenders and its Top 10 Innovators in 2017 and 2016 (Table 2 and Fig. 4) reveals the following:

- only four companies in 2016 (Samsung, Amazon, Alphabet, and Microsoft) and five companies in 2017 (the above-mentioned plus Apple) can be found on both lists of Top 10 Spenders and Top 10 Innovators (all of them being also on both of the 2018 lists);

- there are three companies - Tesla, Facebook, and General Electric - that have been constant presences in Top 10 Innovators between 2016 and 2018, and never have been in Top 10 Spenders during the reference period, while other two companies Volkswagen and Roche - have been constant presences in Top 10 Spenders between 2016 and 2018 and have never reached the Top 10 Innovators during that period; -

- 2016 Top 10 Innovators and 2017 Top 10 Innovators share nine companies - Apple, Alphabet, Tesla, Amazon, Samsung, Facebook, Microsoft, General Electric, and IBM (except for IBM, the other seven companies are also on the 2016 Top 10 Innovators list);

- in 2016: (a). the Top 10 Spenders have spent together \$112,1B on R\&D (highest level: Volkswagen - \$13,2B, lowest level: Toyota - \$8,8B), while the Top 10 Innovators have spent together $\$ 74,3 B$ on R\&D (highest level: Samsung - \$12,7B, lowest level: Tesla $\$ 0,7 \mathrm{~B})$ - which represent $16,5 \%$ and $10,9 \%$ respectively out of the total $\$ 680 \mathrm{~B}$ spent on R\&D by the Global Innovation 1000 companies; (b). the levels of the R\&D Intensity have varied between $3,7 \%$ (Toyota) and $21,9 \%$ (Intel) - amongst the Top 10 
Spenders, and between 3,5\% (Apple) and 26,9\% (Facebook) - amongst the Top 10 Innovators;

- in 2017: (a). a 3,23\% increase in R\&D spending made by Global Innovation 1000 companies corresponds to a 7,6\% increase in R\&D spending made by Top 10 Spenders (up to $\$ 120,6 \mathrm{~B}$ ) and a $13,7 \%$ increase in R\&D spending made by Top 10 Innovators (up to $\$ 84,5 B$ ); (b). the levels of $R \& D$ spending have varied: (b1). between $\$ 9,6 \mathrm{~B}$ (Novartis) and \$16,1B (Amazon) - for the Top 10 Spenders; Between $\$ 0,8 \mathrm{~B}$ (Tesla) and \$16,1B (Amazon) - for the Top 10 Innovators; (c). the R\&D Intensity have varied: (c1). between 4,7\% (Apple) and 25,4\% (Merck) - for the Top 10 Spenders; (c2). between 4\% (General Electric) and 21,4\% (Facebook) - for the Top 10 Spenders.

Fig 4. PwC's Top 10 Spenders vs PwC's Top 10 Innovators 2016-2018 2018 Top 10 Spenders 2018 Top 10 Innovators

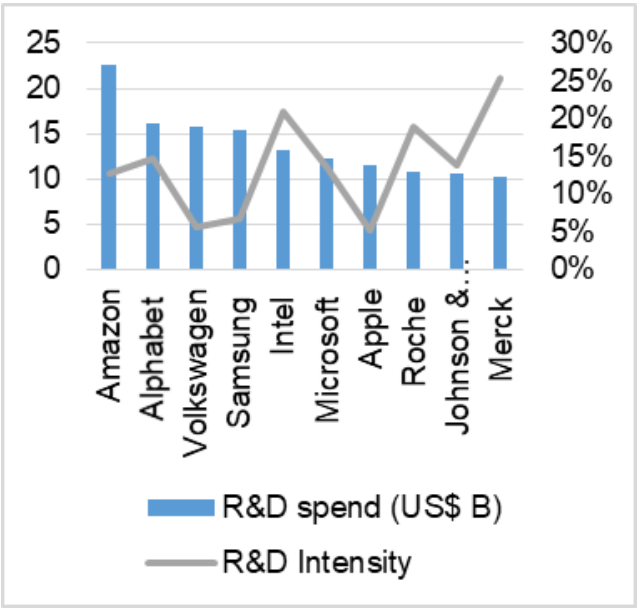

2017 Top 10 Spenders

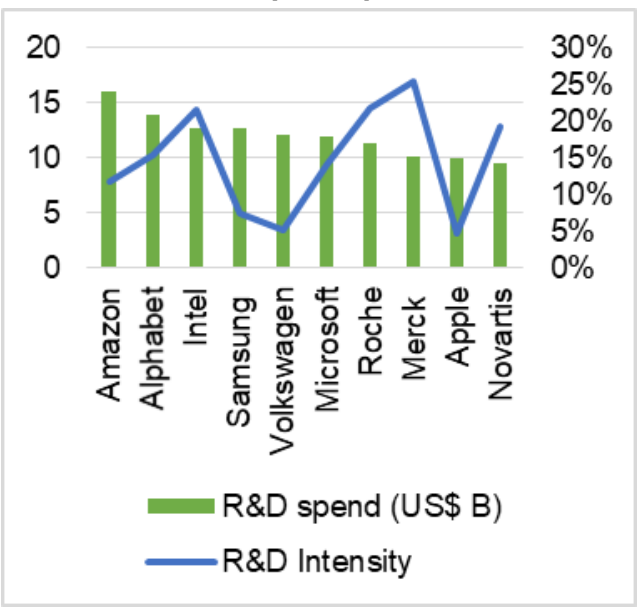

2016 Top 10 Spenders

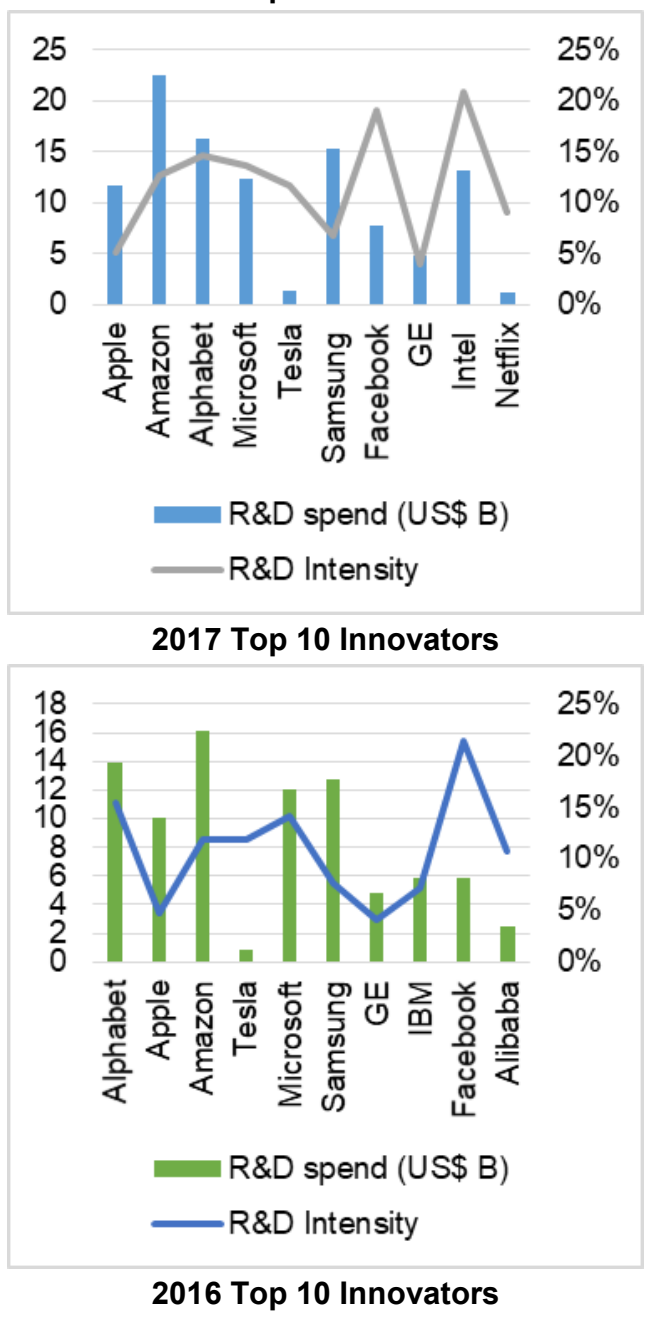




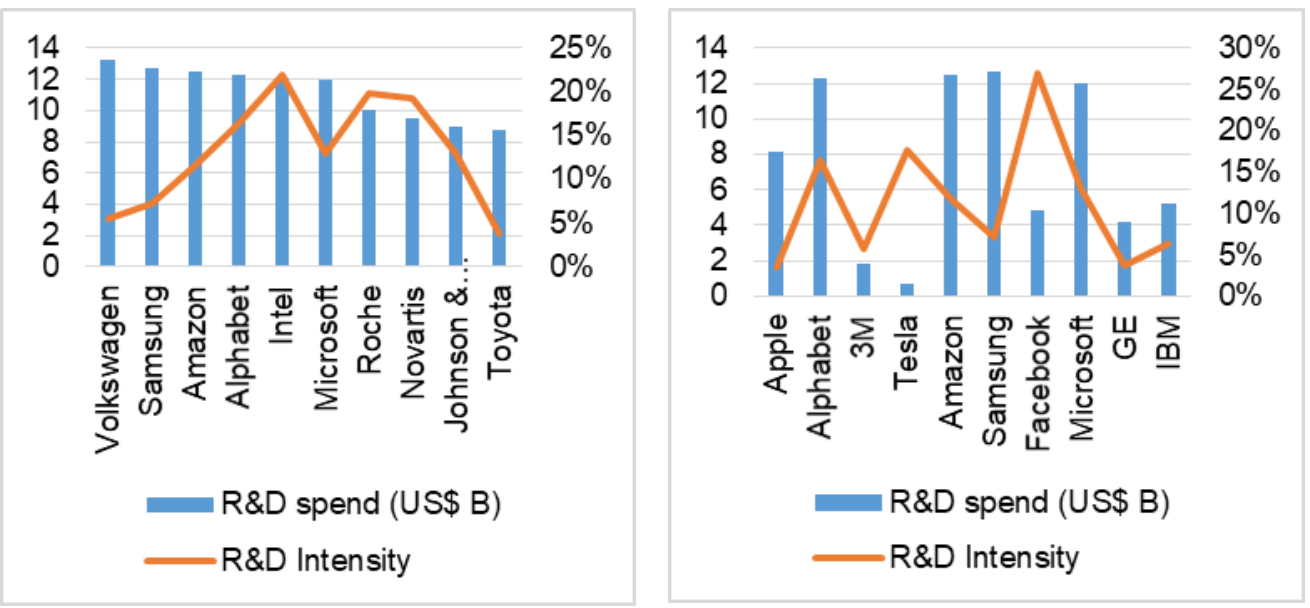

Source of Data: PwC, 2016-2018

Corroborating the spending patterns of Top 10 Spenders and Top 10 Innovators with some key performance indicators that characterize these companies' dynamics (Fig. 5), PwC concludes (while reinforcing its previous similar findings): "there is no long-term correlation between the amount of money a company spends on its innovation efforts and its overall financial performance. Instead, what matters is how companies use that money and other resources, as well as the quality of their talent, processes, and decision making, to create products and services that connect with their customers" (PwC, 2018).

Fig. 5. Top 10 Innovators vs. Top 10 Spenders - Key Performance Indicators (20162018)

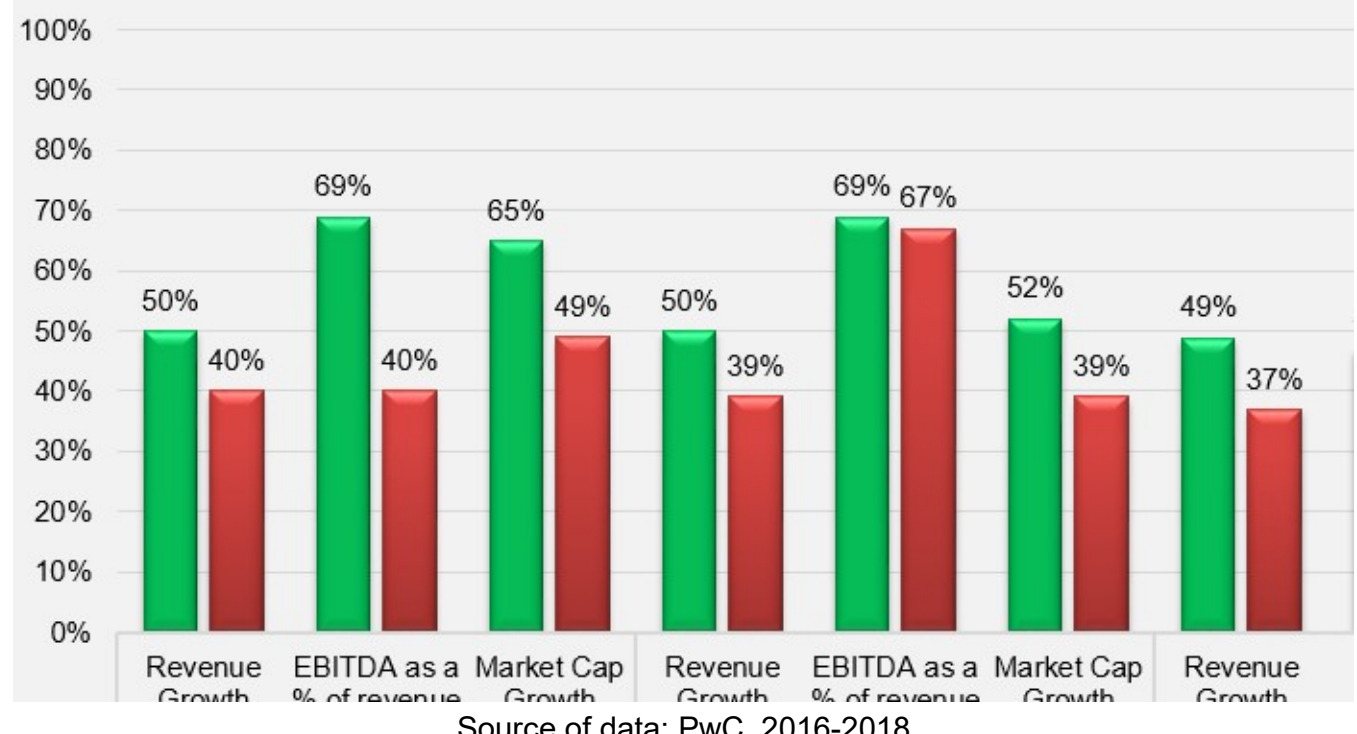




\section{Conclusions}

The main conclusions of the paper can be summarized as follows:

- both the theory and practice of innovation at firm/company level have reached a high level of complexity, while exhibiting multiple facets, valences and outcomes;

- due to the new circumstances that define "the world of" innovation and its broader (global) context, innovation can no longer be an option (but a perennial must - a marathon, not a sprint) and each company has to become (to a certain degree) an innovative company - in order to survive;

- $\quad$ BCG's lists of Steady Innovators and Top 10 Most Innovative Companies proves that innovative companies have to be both coherent (at a given moment) and consistent (in time) in their pursue of innovation;

- the power of digitalization - to transform both the search for innovation and the (resulted) global architecture of innovation, while redefining / reshaping industries - is the one that stands out from the BCG's 2016-2018 rankings of the Most Innovative Companies;

- PwC's Global Innovation 1000 Study demonstrates the increasing emphasis companies have put (during the last decade) on their R\&D spending (both in nominal terms and as percentage of their revenue) as precursors of innovation;

- PwC's analyses have (repeatedly) negated the existence of a "long-term correlation between the amount of money a company spends on its innovation efforts and its overall financial performance" (PwC, 2018);

- there are seven companies that share both rankings (BCG's and PwC's) of Top 10 Innovators during 2016-2018 - Alphabet, Amazon, Apple, Microsoft, Samsung, Facebook, and Tesla - all of them massively betting on digitalization.

Future research will envisage developing a complexity-based framework for the innovative organization - built on the main characteristics of the world's most innovative companies and able to provide guidance for companies on their way of becoming innovative ones.

\section{References}

Abernathy, W. J., \& Utterback, J. M. (1978). Patterns of industrial innovation. Technology review, 80(7), 40-47.

Amidon, D. M. (2009). Innovation strategy for the knowledge economy. Routledge.

Andersen, M. M. (2008, June). Eco-innovation-towards a taxonomy and a theory. In 25th celebration DRUID conference.

Andriopoulos, C., \& Lewis, M. W. (2009). Exploitation-exploration tensions and organizational ambidexterity: Managing paradoxes of innovation. Organization science, 20(4), 696-717.

Anthony, S. D., Eyring, M., \& Gibson, L. (2006). Mapping your innovation strategy. Harvard business review, 84(5), 104-13.

Becker, S. W., \& Whisler, T. L. (1967). The innovative organization: A selective view of current theory and research. The journal of Business, 40(4), 462-469.

Beer, M., \& Walton, A. E. (1987). Organization change and development. Annual review of psychology, 38(1), 339-367. 
Bessant, J., \& Tidd, J. (2007). Innovation and entrepreneurship. John Wiley \& Sons.

Bossle, M. B., de Barcellos, M. D., Vieira, L. M., \& Sauvée, L. (2016). The drivers for adoption of ecoinnovation. Journal of Cleaner production, 113, 861-872.

Boston Consulting Group (BCG). (2019). The Most Innovative Companies: an Interactive Guide. https://www.bcg.com/publications/collections/most-innovative-companies-2019-artificialintelligence-platforms-ecosystems.aspx.

Bruns, T., \& Stalker, G. M. (1961). The management of innovation. Tavistock, London, 120-122.

Camisón, C., \& Villar-López, A. (2014). Organizational innovation as an enabler of technological innovation capabilities and firm performance. Journal of business research, 67(1), 2891-2902.

Chauvel, D., \& Borzillo, S. (2017). The Innovative Company: An III-defined Object. John Wiley \& Sons.

Chesbrough, H. W. (2003). Open innovation: The new imperative for creating and profiting from technology. Harvard Business Press.

Christiansen, J. (2000). Building the innovative organization: Management systems that encourage innovation. Springer.

Cohen, W. M., \& Levinthal, D. A. (1989). Innovation and learning: the two faces of R \& D. The economic journal, 99(397), 569-596.

Cohen, W. M., \& Levinthal, D. A. (1990). Absorptive capacity: A new perspective on learning and innovation. Administrative science quarterly, 35(1), 128-152.

Damanpour, F. (1991). Organizational innovation: A meta-analysis of effects of determinants and moderators. Academy of management journal, 34(3), 555-590.

Damanpour, F., Szabat, K. A., \& Evan, W. M. (1989). The relationship between types of innovation and organizational performance. Journal of Management studies, 26(6), 587-602.

de Vasconcelos Gomes, L. A., Facin, A. L. F., Salerno, M. S., \& Ikenami, R. K. (2018). Unpacking the innovation ecosystem construct: Evolution, gaps and trends. Technological Forecasting and Social Change, 136, 30-48.

Denervaud, I., \& Chatin, O. (2011). DNA Profiling: The Innovative Company: how to Increase Creative Ability in Business. Pearson Education France.

Dodgson, M., Gann, D. M., \& Phillips, N. (Eds.). (2013). The Oxford handbook of innovation management. OUP Oxford.

Drucker, P. (2014). Innovation and entrepreneurship. Routledge.

Dyer, J., \& Gregersen, H. (2018). How We Rank The Most Innovative Companies 2018. https://www.forbes.com/sites/innovatorsdna/2018/05/29/how-we-rank-the-most-innovativecompanies-2018/\#6f997dca1e3c.

Fernandes, A. M., \& Paunov, C. (2012). The risks of innovation: Are innovating firms less likely to die?. The World Bank.

Freeman, C. (2013). Economics of industrial innovation. Routledge.

Gassmann, O., Enkel, E., \& Chesbrough, H. (2010). The future of open innovation. R\&d Management, 40(3), 213-221.

Glor, E. D. (2002, February). Innovation traps: Risks and challenges in thinking about innovation. In Workshop on Public Sector Innovation.

Grossman, G. M., \& Helpman, E. (1991). Innovation and growth in the global economy. MIT press.

Gunday, G., Ulusoy, G., Kilic, K., \& Alpkan, L. (2011). Effects of innovation types on firm performance. International Journal of production economics, 133(2), 662-676.

Hamel, G., \& Tennant, N. (2015). The 5 requirements of a truly innovative company. Harvard Business Review, 27.

Henderson, R. M., \& Clark, K. B. (1990). Architectural innovation: The reconfiguration of existing. Administrative science quarterly, 35(1), 9-30.

Jackson, D. J. (2011). What is an innovation ecosystem. National Science Foundation, 1. 
Jaruzelski, B., Chwalik, R., \& Goehle, B. (2018). What the Top Innovators Get Right. Strategy+Business. 93. https://www.strategy-business.com/feature/What-the-Top-InnovatorsGet-Right?gko=e7cf9.

Jaruzelski, B., Staack, V., \& Chwalik, R. (2017). Will Stronger Borders Weaken Innovation?. Strategy+Business. 24. https://www.strategy-business.com/feature/Will-Stronger-BordersWeaken-Innovation?gko $=5 \mathrm{~d} 1 \mathrm{cf}$.

Jaruzelski, B., Staack, V., \& Shinozaki, A. (2016). Software-As-A-Catalyst. Strategy+Business. 25. https://www.strategy-business.com/feature/Software-as-a-Catalyst?gko=9e52b.

Kaufmann, A., \& Tödtling, F. (2001). Science-industry interaction in the process of innovation: the importance of boundary-crossing between systems. Research policy, 30(5), 791-804.

Keeley, L., Walters, H., Pikkel, R., \& Quinn, B. (2013). Ten types of innovation: The discipline of building breakthroughs. John Wiley \& Sons.

Kleinknecht, A., \& Mohnen, P. (Eds.). (2001). Innovation and firm performance: Econometric explorations of survey data. Springer.

Lam, A. (2011, April). Innovative organisations: Structure, learning, and adaptation. In Paper presented at the DIME Final Conference (Vol. 6, p. 8).

Lin, H. E., McDonough III, E. F., Lin, S. J., \& Lin, C. Y. Y. (2013). Managing the exploitation/exploration paradox: The role of a learning capability and innovation ambidexterity. Journal of Product Innovation Management, 30(2), 262-278.

Lockwood, T., \& Walton, T. (2010). Corporate Creativity: Developing an Innovative Organization. Simon and Schuster.

Lundvall, B. A. (Ed.). (2010). National systems of innovation: Toward a theory of innovation and interactive learning (Vol. 2). Anthem press.

Markides, C. (1998). Strategic innovation in established companies. MIT Sloan Management Review, 39(3), 31.

McElroy, M. W. (2003). The new knowledge management: Complexity, learning, and sustainable innovation. Routledge.

Mohr, L. B. (1969). Determinants of innovation in organizations. American political science review, 63(1), 111-126.

Mulgan, G., Tucker, S., Ali, R., \& Sanders, B. (2007). Social innovation: what it is, why it matters and how it can be accelerated.

Murray, R., Caulier-Grice, J., \& Mulgan, G. (2010). The open book of social innovation (p. 2). London: National endowment for science, technology and the art.

Nechaev, A. S., Antipina, O. V., \& Prokopyeva, A. V. (2014). The risks of innovation activities in enterprises. Life Science Journal, 11(11), 574-575.

Nelson, R. R. (Ed.). (1993). National innovation systems: a comparative analysis. Oxford University Press on Demand.

PriceWatterhouseCoopers. (PwC). The 2018 Global Innovation 1000 Study. https://www.strategyand.pwc.com/gx/en/insights/innovation1000.html.

Ringel, M., Grassl, F., Baeza, R., Kennedy, D, Spira, M., \& Manly, J. (2019). The most innovative companies 2019. The rise of Al, Platforms and Ecosystems. The Boston Consulting Group (BCG). https://www.directivosyempresas.com/wp-content/uploads/2019/04/BCG-MostInnovative-Companies-2019.pdf.

Ringel, M., Taylor, A., \& Zablit, H. (2017). The most innovative companies 2016. Getting Past "Not Invented Here". The Boston Consulting Group (BCG). http://image-src.bcg.com/lmages/BCGThe-Most-Innovative-Companies-2016-Jan-2017_tcm9-163125.pdf.

Ringel, M., Zablit, H., Grassl, F., Manly, J, \& Moller, C. (2018). The most innovative companies 2018. Innovators Go All In On Digital. The Boston Consulting Group (BCG). http://imagesrc.bcg.com/Images/BCG-Most-Innovative-Companies-Jan-2018_tcm9-180700.pdf. 
Robertson, T. S. (1967). The process of innovation and the diffusion of innovation. Journal of marketing, 31(1), 14-19.

Rothaermel, F.T. (2017). Strategic Management. McGraw-Hill Education.

Salaman, G., \& Storey, J. (2002). Managers' theories about the process of innovation. Journal of Management studies, 39(2), 147-165.

Schlegelmilch, B. B., Diamantopoulos, A., \& Kreuz, P. (2003). Strategic innovation: the construct, its drivers and its strategic outcomes. Journal of strategic marketing, 11(2), 117-132.

Schot, J., \& Geels, F. W. (2008). Strategic niche management and sustainable innovation journeys: theory, findings, research agenda, and policy. Technology analysis \& strategic management, 20(5), 537-554.

Seidler-de Alwis, R., \& Hartmann, E. (2008). The use of tacit knowledge within innovative companies: knowledge management in innovative enterprises. Journal of knowledge Management, 12(1), 133-147.

Smith, K. R. (2006). Building an innovation ecosystem: Process, culture and competencies. Industry and higher education, 20(4), 219-224.

Tidd, J., \& Bessant, J. R. (2018). Managing innovation: integrating technological, market and organizational change. John Wiley \& Sons.

Verdu-Jover, A. J., Llorens-Montes, J. F., \& Garcia-Morales, V. J. (2005). Flexibility, fit and innovative capacity: an empirical examination. International Journal of Technology Management, 30(1-2), 131-146.

Von Hippel, E. (2007). The sources of innovation. In Das Summa Summarum des Management (pp. 111-120). Gabler.

Wakelin, K. (1998). Innovation and export behaviour at the firm level. Research policy, 26(7-8), 829841. 